\title{
EFFECT OF PHYTASE AND ENZYMES MIXTURE SUPPLEMENTATION ON SOME PHYSIOLOGICAL RESPONSES OF BROILER CHICKS
}

Kawsar A. Ghaly*; A. M. A. Osman; S. A. Abd EL-Latif; Kh. A. Mohammed; and Maha A. Abd El-Latif

Dep. of Anim. Prod. Fac. of Agric., Minia Univ., Minia, Egypt

*Corresponding author: kawsar Ghaly; Email: kawsarghaly@yahoo.com

\begin{abstract}
Received:10/04/2017
Accepted:25/04/2017

ABSTRACT: This study was carried out to study the effect of enzymes mixture and phytase supplementation in sorghum-soybean meal diets on some physiological responses of broiler chicks. One hundred ninety-two, unsexed, day old Hubbard broiler chicks were randomly distributed into six groups with four replicates each with eight chicks. Three diets from each of the starter and grower based on sorghum- soybean meal were formulated to have either recommended, medium or low levels of both crude protein and metabolizable energy. The first starter and grower diets were served as control dietary treatment (D1). The second (D2) and third (D3) starter and grower diets were formulated to have gradually decreased levels of both crude protein by $2 \%$ and $4 \%$ and metabolizable energy 300 and $600 \mathrm{kcal} / \mathrm{kg}$ for diet D2 and D3, respectively. Starter and grower diets were supplemented with or without enzymes. The data reviled that, values of serum glucose, total protein and it's fractions (albumin and globulin), total lipids, calcium and phosphorus $(\mathrm{mg} / \mathrm{dl})$ were increased $(\mathrm{p}<0.05)$ with enzymes supplementation. However, liver enzymes (ALT and AST) and thyroid hormones (T3 and T4) of broiler chicks were not significantly affected by cocktail enzymes supplementation. While, the activity of ALT was decreased $(\mathrm{p}<0.05)$ with decreasing $\mathrm{CP} \%$ and $\mathrm{ME}$ level by $2 \%$ and $300 \mathrm{kcal} / \mathrm{kg}$, respectively less than the recommended level, but no further decrease in ALT activity was observed by decreasing CP\% and ME energy beyond the previously mentioned level. However, AST activity showed no clear trend in relation to the level of both protein and energy. From the present results, it can be concluded that using mixture and phytase enzymes into sorghum-soybean meal diet could be lead to improvement on some physiological responses of broiler chicks.
\end{abstract}

Key words: Broiler chicks - Phytase - Enzymes - Physiological responses. 


\section{INTRODUCTION}

Sorghum grain can replace maize in poultry feed to a great extent in view of the similarity in chemical composition of the grain. The results on egg production and broiler weight were similar in two experiments when sorghum or maize was fed as a source of energy. Local sorghum grain was effective as high-yielding sorghum or maize. Thus, sorghum grain has a high potential for use in poultry feed (Subramanian and Metta, 2000). The nutrient profile of sorghum is complementary to protein sources typically formulated in poultry rations anywhere in the world and is very similar to corn (maize). Nyannor et al. (2007) concluded that growth performance of broiler chicks was equally supported by corn or sorghum.

The proximate analysis of sorghum compared to corn (according to NRC, 1994) indicates that the cereal grains are similar where sorghum contains less oil and slightly more non-phytate phosphorus. Kriegshauser et. al. (2006) indicated that sorghum had higher values of protein as expected, while the energy or fat content of sorghum was slightly lower than that of corn. The amino acid profile of the sorghums compared well to corn, although the average lysine content of sorghum tested to be $0.26 \%$ versus corn at $0.30 \%$. Huang et al. (2006) conducted a unique study to compare the apparent digestibility of sorghum to corn using broilers, layers and mature leghorn roosters. Crude protein digestibility of sorghum versus corn in all three classes of birds was similar between the grain sources. However, lysine and methionine amino acids were slightly more digestible in the corn samples. Similar results were obtained by Lemme et al. (2004).

A research group studied the effect of adding a commercial mixture of pectinases, a-glucanases, and hemicellulases to sorghum-soy feed rations for broilers. Dominguez et al (2009) found that amino acid digestibility increased $3 \%$, while the metabolizable energy (ME) was increased by over $6 \%$ when used in rations that were marginal in nutrients. This demonstrates that enzymes can be used to get more nutrients from sorghum. Similarly, Cadogan et al. (2005) found that adding phytase enzyme on sorghum-based diets improved weight gain, amino acid digestibility, starch digestibility and performance of broilers. Limited studies do indicate that there are opportunities to use enzyme preparations to improve bird performance. However, the database is currently lagging behind similar studies for wheat, barley, and corn. Therefore, the present study was carried out to study the effect of diets based on sorghum/soybean meal which having different levels of protein and energy with constant $\mathrm{C} / \mathrm{P}$ ratio, and supplement with the commercial mixture of enzymes (amylase, protease, and cellulose) and phytase enzyme on some blood constituents in commercial broiler chickens.

\section{MATERIALS AND METHODS}

A total number of one hundred ninety-two unsexed, day old Hubbard broiler chicks were used in this study. Chicks were randomly distributed into 6 groups with 4 replicates each. All chicks were housed in two-tiers floor batteries located in an open house. The dimensions of the cage in each battery were $(100 \times 60 \times 40 \mathrm{~cm})$ for length, width, and height, respectively. Average initial body weight of all treatments was almost similar. Three diets within each of the starter and grower diets plant origin were formulated to have recommended medium or low levels of both crude protein and metabolizable energy. The first starter and grower diets were formulated to meet the nutrients requirements of broiler chicks according to NRC (1994) and served as a control treatment. The second and third starter and grower diets were formulated to have gradually decreased levels of both crude proteins by about $2 \%$ and $4 \%$ and 
metabolizable energy by about 300 and 600 $\mathrm{kcal} / \mathrm{kg}$ diet. Both starter and grower diets were formulated to have similar $\mathrm{C} / \mathrm{P}$ ratio and similar levels of calcium, phosphorus, lysine and sulphuric acids as recommended by NRC (1994). Also, both starter and grower diets were supplemented with and without mixture of enzymes (Natuphos 1 $\mathrm{kg} /$ ton plus Vetazyme $250 \mathrm{~g} / \mathrm{ton}$ feed). Each $1 \mathrm{~kg}$ Natuphos contained 500000 FTU phytase and each $1 \mathrm{~g}$ Vetazyme contained amylase $500 \mathrm{U}$, protease $2000 \mathrm{U}$, cellulase $400 \mathrm{U}$ and lactobacillus acidophilus 200 million CFU. The previous levels of enzymes supplementation were recommended by the manufacturer. All diets were formulated from sorghum grains as a main and untraditional source of energy. The formula and chemical composition of the experimental diets are shown in Table (1). All chicks were full access to feed and water during the experimental period (from 0 to 6 wks. of age).

All groups were randomly allocated in batteries and kept under similar conditions of management. Artificial lighting was provided 24 hours during the first 10 days of age, then the artificial light was used in the evening only. The temperature in the brooding house was about $36^{\circ} \mathrm{C}$ for the first 3 days of age, after that, it was reduced 2 degrees every week until the fourth week. Then, the temperature was kept at $25^{\circ} \mathrm{C}$ till the end of experiment. Chicks in each replicate were weighed to the nearest gram at the beginning of the experiment (at 1 day of age) and at the end.

At the end of experiment (slaughtering), blood samples were collected from each experimental group ( 3 birds $\times 2$ samples $\times 6$ treatments $=36$ samples). The blood samples were collected in non-heparinized tubes to obtain serum. The tubes putted horizontally for 20 minutes to clot, then centrifuged at $3000 \mathrm{rpm}$ for 20 minutes to obtain the serum and the sera were stored at $-20{ }^{\circ} \mathrm{C}$ until analysis.

\section{Studied Traits:}

Serum total protein and albumin concentration were determined according to the method of (Gornal et al., 1949) and (Tietz and Saunders, 1995), while globulin concentration was calculated by subtracting TP by Alb according to the following equation: Globulin $(\mathrm{g} / \mathrm{dl})=$ Total protein $(\mathrm{g} / \mathrm{dl})$ - Albumin $(\mathrm{g} / \mathrm{dl})$. Serum glucose $(\mathrm{mg} / \mathrm{dl})$ concentration was determined according to the method of Trinder (1969). Serum total lipid (g/dl) was determined according to Zollner and Kirsch (1962). Serum calcium and phosphorus were determined according to Gindler and King (1972) and El-Merzabani et al. (1977). Liver enzymes (Alanine amino transaminase and Aspartate amino transaminase) activities in the serum were determined according to Reitman and Frankle (1957). Thyroid hormones, Triiodothyronine (T3) and thyroxin (T4), concentrations were determined by a direct solid-phase $\mathrm{I}^{125}$ radio immunoassay techniques using (Coat-ACoat TK T3 and TK T4) RIA kits purchased from diagnostic products corporation (DPC, Los Angeles, CA, 90045-5597 USA) at the laboratory of Atomic Energy Authority in Egypt, while ratio of T3/T4 was calculated according to the following equation: $\mathrm{T} 3 / \mathrm{T} 4$ ratio $=\mathrm{T} 3$ value $/ \mathrm{T} 4$ value .

\section{Statistical analysis:}

Data were statistically analyzed by the analysis of variance using the General Linear Model (GLM) procedure of Statistical Analysis System (SAS, 2004). Significant differences among treatments were separated by Duncan's multiple range tests (Duncan, 1955).

The following statistical model was used:

$Y_{i j k}=M+D_{i}+E_{j}+D E_{i j}+e_{i j k}$

Where: $\mathrm{Y}_{\mathrm{ijk}}=$ an observation measured, $\mathrm{M}=$ the overall mean, $D_{i}=$ effect of dietary treatment, $E_{j}=$ effect of enzymes mixture, $D_{i j}=$ effect of interaction $\left(D_{i} \times E_{j}\right), e_{i j k}=$ experimental error. 


\section{RESULTS AND DISCUSSION Serum total protein, albumin, globulin, glucose, calcium and phosphorus: Effect of enzyme:}

The obtained results (Table 2) shows that the values of glucose, total protein, albumin, globulin, calcium, and phosphorus were increased $\quad(p<0.05)$ with enzyme supplementation. This increase may be due to the improvement in digestibility and availability of nutrients resulted from multienzymes supplementation. Multi-enzymes contained amylase, led to break starch into sugars. Also protease breaks down proteins by proteolysis of the peptide bonds that link amino acids together in the polypeptide chain forming the protein. In addition cellulase catalyze the hydrolysis of cellulose and phytase break down phytates in the feed to release inorganic phosphorus and inositol as well as protein, amino acids, trace minerals and other nutrients chelated with phytase. These results agree with that reported by Olukosi et al. (2007) who indicated that the improvements in nutrients digestibility by enzyme supplementation can be a reason for increasing blood glucose concentration in broiler chicks. Also, Hajati et al. (2009) found that adding enzymes (Endo feed $\mathrm{w}+$ xylanase $+\beta$-glucanase) to broiler chick diets increased blood glucose at 44 days of age. However, Jalali and Babaei (2012) illustrated that serum total protein and albumin concentrations were increased by phytase addition to broiler chick diets. Safaa (2013) reported that enzyme supplementation which contains xylanase, cellulase, protease and $\alpha$-amylase to broiler chick diets increased plasma total protein and globulin at 42 days of age. It is well known that, phosphorus (P) in phytate is low availability $(20-30 \%)$ to monogastric animals because the lack proper enzyme system to hydrolysis phytate. Phytate phosphorus represented about $60-70 \%$ of total phosphorus in plant origin. It is well documented that, phytase supplementation enhance phytate hydrolysis and increase availability of nutrients bound to phytic molecule ( Sebastain et. al., 1997 ). Also phytase addition liberates calcium ions, these ions are necessary for $\alpha$-amylase activity which is involved in starch digestion (Ravindran et al., 1999; and Kies et al., 2001). Also, Abou El-Wafa et al. (2005) indicated that, phytase decrease $\mathrm{P}$ excretion and improved mineral availability such as $\mathrm{Zn}, \mathrm{Fe}, \mathrm{Ca}$ and $\mathrm{K}$ of poultry diets.

\section{Effect of diet:}

The presented results in Table (2) indicates that birds fed on medium level of protein and energy $\left(D_{2}\right)$ recorded the highest $(p<0.05)$ value of glucose followed by those fed on low level of protein and energy $\left(\mathrm{D}_{3}\right)$. However, birds fed on the diet of high protein and energy $\left(D_{1}\right)$ recorded the lowest $(\mathrm{p}<0.05)$ values of glucose. Concerning the effect of dietary treatments on calcium and phosphorus values, birds fed diets with recommended $\left(D_{1}\right)$ or medium $\left(D_{2}\right)$ levels of protein and energy had similar values of both two elements but higher $(\mathrm{p}<0.05)$ than those fed on the diet of low protein and energy level $\left(D_{3}\right)$. These differences could be attributed to the difference in digestibility and availability of nutrients.

Also, results indicated that, enzymes mixture supplementation into diets having different levels of protein and energy with constant $\mathrm{C} / \mathrm{P}$ ratio had significantly $(\mathrm{p}<0.05)$ effect on blood glucose and insignificantly effect on blood total protein, albumin, globulin, calcium and phosphorus of broiler chicks at 42 days of age.

\section{Interaction effects:}

The results (Table 2) showed that the enzyme addition to the diets of high, medium or low protein and energy levels increased $(p<0.05)$ blood serum glucose in broiler chicks. This increase represented about 32.23, 23.22 and $31.77 \%$ when enzymes mixture were added to diet 1, 2 and 3 , respectively compared to their counterparts un-supplemented dietary treatment. Also, enzyme supplementation insignificantly increased total protein, albumin, calcium and phosphorus values in 
blood serum of broiler chicks and this effect was not dependent on diet composition.

These results agree partially with Bedford (2000) and Acamovic (2001) who indicated that, the effects of exogenous enzymes can be variable and it depends on a large number of factors such as the age of birds and the quality and type of diet. Also, Sadaka (2006) reported that, the addition of phytase to either high or low ME diets increased calcium release, which confirmed the effective role of phytate in releasing calcium from phytase complex. Also, results were in full agreement with Buyse et al. (2002) and Swennen et al. (2005) who indicated that nutritional factors (diet quantity and composition) affect intermediary metabolism resulting in the change of plasma metabolic levels in poultry. While, Rabie et al. (2010) found that ME levels had an insignificant effect on glucose, total protein, albumin and globulin values in broiler chicks. In addition, Mossad and Iben (2009) reported that calcium and phosphorus in blood serum increase with increasing $\mathrm{CP}$, whilst dietary energy did not affect the serum level of them in Japanese quails.

Total lipids, liver enzymes, and thyroid hormones:

\section{Effect of enzymes:}

The averages of serum total lipids, liver enzyme activities, thyroid hormones $\left(\mathrm{T}_{3}, \mathrm{~T}_{4}\right)$ and the ratio of $T_{3} / T_{4}$ values as affected by multi-enzymes supplementation into diets of broiler chicks based on the sorghumsoybean meal are presented in Table (3). Enzymes addition had a significant $(\mathrm{p}<0.01)$ effect only on serum total lipids. The opposite was true with its effects on AST, ALT, $T_{3}, T_{4}$ and $T_{3} / T_{4}$ ratios which were insignificant. The increase in serum total lipids by enzyme supplementation may be due to the increase in nutrients digestibility, availability, absorption, and metabolic rates. Viveros et al. (2002) found that phytase supplementation increased serum AST but decreased ALT activity. Hajati et al. (2009) reported that adding enzyme increased total fat, whereas the concentration of blood thyroxin $\left(\mathrm{T}_{4}\right)$ in broiler chicks at 42 days of age was reduced. Shanti et al. (2012) indicated that, phytase supplementation at the level of 600 FTU increased ALT in blood serum of broiler chicks, while the values of AST were not affected. Shehab et al. (2012) found an insignificant effect of Kemzyme, phytase or their mixture on AST and $T_{4}$ values, while $T_{3}$ value was decreased by phytase supplementation in Japanese quail diets. Also, Safaa (2013) indicated that enzymes addition (ZADO) which contained xylanase, cellulase, protease and $\alpha$-amylase into broiler chick diets had no significant effect on AST and ALT values.

\section{Effect of diets:}

Total lipids, liver enzyme activities, and $\mathrm{T}_{3}$ hormone were significantly $(\mathrm{p}<0.01)$ affected by dietary treatments of broiler chicks, while $T_{4}$ and $T_{3} / T_{4}$ values were insignificantly affected. Birds fed on low protein and energy diets recorded the highest $(\mathrm{p}<0.05)$ value $(\mathrm{mg} / \mathrm{dl})$ of total lipids followed by those fed on the control diet. However, birds fed on the diets medium protein and energy level had the lowest value $(p<0.05)$ of serum total lipids. Birds fed on the medium level of protein and energy had higher values $(p<0.05)$ of ALT enzymes compared to those fed on low protein and energy level, while those fed on recommended protein and energy level had intermediate ALT value. The highest value $(p<0.05)$ of AST enzyme was recorded for birds fed on the control dietary treatment. However, those fed on medium or low protein and energy levels achieved similar AST values. Rabie et al. (2010) reported that the level of ME had insignificant effect on activities of AST and ALT in blood plasma of broiler chicks. The value of $\mathrm{T}_{3}$ hormone was higher $(\mathrm{p}<0.05)$ in birds fed the medium $\left(D_{2}\right)$ protein and energy level compared to those fed on the control $\left(D_{1}\right)$ diet, while those fed low $\left(D_{3}\right)$ protein and energy level had intermediate $\mathrm{T}_{3}$ value. 
Kawsar A. Ghaly et. al.

It could be concluded from these results that decreasing the crude protein and ME by about $2 \%$ and $300 \mathrm{kcal} / \mathrm{kg}$ down the recommended levels decreased serum total lipids. However, the successive decrease of $\mathrm{CP}$ and ME by about (4\% CP and $600 \mathrm{kcal}$ $\mathrm{ME)}$ less than the control dietary treatment resulted in an increase of serum total lipids in broiler chicks at 42 days of ages. Also, AST activity was decreased $(\mathrm{p}<0.05)$ with decreasing protein and energy level by about $2 \%$ and $300 \mathrm{kcal} \mathrm{ME} / \mathrm{kg}$, respectively, but no further decrease in AST activity with decreasing the content of protein and energy beyond the previously mentioned level. The value of Triiodothyronine $\left(\mathrm{T}_{3}\right)$ was increased $(p<0.05)$ with decreasing the level of protein and energy by about $2 \% \mathrm{CP}$ and $300 \mathrm{kcal}$ $\mathrm{ME} / \mathrm{kg}$ less than the recommended level. However, the value of $T_{4}$ and $T_{3} / T_{4}$ ratios in blood plasma were not significantly changed with decreasing protein and energy levels. So, nutrition is an important factor in the regulation of plasma hormones and their receptors gene expression in many tissues of chickens. For example, protein deficiency changes the ratio of circulating concentration of $T_{3}$ and $T_{4}$, reduces circulating concentrations of IGF-1 and increase GH concentration (Scanes and Griminger, 1990). Swennen et al., (2005 and
2006) reported that generally plasma $\mathrm{T} 3$ concentrations was increased whereas $\mathrm{T}_{4}$ concentrations was decreased with low crude protein $(\mathrm{CP})$ diets which partially coincided with the present results. It is well known, that metabolic activity needs more secretion of thyroid hormone particularly $\mathrm{T}_{3}$ hormone which is the biologically active hormone (Smith et al., 1998).

Abdel-Azeeme (2011) reported that total lipids were decreased by reducing $\mathrm{CP}$ and $\mathrm{ME}$ in the diets of Japanese quails. He also reported that, AST and ALT values were increased by reducing $\mathrm{CP}$ and $\mathrm{ME}$ in the diets. Also, Kout El-Kloub et al. (2010) indicated that, total lipids and cholesterol values were decreased by high ME level.

\section{Interaction effects:}

The effect of interaction (Diet $x$ Enzymes) on total lipids liver enzymes and thyroid hormones values were insignificant except on thyroxin values and AST which was higher $(\mathrm{p}<0.05)$ for birds fed on the control diet $\left(D_{1}\right)$ supplemented with enzyme mixture (Table 3 ). From these results, it could be concluded that enzymes addition into broiler chick diets had no detrimental effect on liver enzymes or thyroid hormones values and their effects were diet independent. 
Broiler chicks - Phytase - Enzymes - Physiological responses.

Table (1): Composition and chemical analysis of the experimental diets

\begin{tabular}{|c|c|c|c|c|c|c|}
\hline \multirow[t]{2}{*}{ Ingredients\% } & \multicolumn{3}{|c|}{ Starter diets } & \multicolumn{3}{|c|}{ Grower diets } \\
\hline & Con. & Diet 2 & Diet 3 & Con. & Diet 2 & Diet 3 \\
\hline Sorghum grains & 56.32 & 58.93 & 50.17 & 64.15 & 66.75 & 55.28 \\
\hline Soybean meal & 27.78 & 21.20 & 15.00 & 19.45 & 11.60 & 6.00 \\
\hline Broiler concentrate & 10.00 & 10.00 & 10.00 & 10.00 & 10.00 & 10.00 \\
\hline Wheat bran & 0 & 7.07 & 22.43 & 0 & 9.00 & 26.42 \\
\hline Vegetable oils & 4.50 & 1.40 & 0.90 & 5.00 & 1.15 & 0.80 \\
\hline Dicalcium phosphate & 0.20 & 0.20 & 0.20 & 0.20 & 0.20 & 0.20 \\
\hline Limestone & 0.70 & 0.70 & 0.70 & 0.70 & 0.70 & 0.70 \\
\hline Common salt & 0.25 & 0.25 & 0.25 & 0.25 & 0.25 & 0.25 \\
\hline Premix* & 0.25 & 0.25 & 0.25 & 0.25 & 0.25 & 0.25 \\
\hline Lysine & 0 & 0 & 0.10 & 0 & 0 & 0.10 \\
\hline Total & 100 & 100 & 100 & 100 & 100 & 100 \\
\hline$\underline{\text { Calculated analysis }}$ & & & & & & \\
\hline Crude protein & 22.92 & 21.15 & 19.31 & 20.11 & 18.07 & 16.39 \\
\hline Metabolizable energy & 3086.1 & 2839.4 & 2569.3 & 3195.8 & 2881.1 & 2574.3 \\
\hline Calcium\% & 1.01 & 1.00 & 1.00 & 0.99 & 0.98 & 0.98 \\
\hline Av. Ph. \% & 0.46 & 0.46 & 0.46 & 0.44 & 0.44 & 0.44 \\
\hline Lysine & 1.24 & 1.10 & 1.10 & 1.03 & 0.89 & 0.91 \\
\hline Meth. + Cys. & 0.83 & 0.80 & 0.80 & 0.76 & 0.75 & 0.74 \\
\hline $\mathrm{CF} \%$ & 3.42 & 3.80 & 4.85 & 3.02 & 3.53 & 3.87 \\
\hline $\begin{array}{l}\mathrm{C} / \mathrm{P} \text { ratio } \\
\text { laboratory analysis }\end{array}$ & 134.65 & 134.25 & 133.06 & 158.92 & 159.44 & 157.07 \\
\hline $\mathrm{DM} \%$ & 90.98 & 90.76 & 90.40 & 90.88 & 89.97 & 89.78 \\
\hline OM \% & 82.15 & 83.90 & 83.32 & 83.49 & 82.62 & 83.08 \\
\hline $\mathrm{CP} \%$ & 23.44 & 21.20 & 19.40 & 19.89 & 17.99 & 16.05 \\
\hline $\mathrm{EE} \%$ & 4.80 & 3.53 & 3.15 & 5.60 & 3.35 & 3.53 \\
\hline NFE \% & 50.26 & 54.75 & 56.30 & 72.98 & 67.74 & 71.28 \\
\hline Ash \% & 8.82 & 6.94 & 7.30 & 7.50 & 7.20 & 5.62 \\
\hline $\mathrm{CF} \%$ & 3.61 & 3.30 & 3.32 & 3.03 & 3.55 & 3.96 \\
\hline Mois. \% & 9.02 & 9.23 & 9.12 & 9.10 & 10.12 & 10.30 \\
\hline
\end{tabular}

* Each 1 kg Premix contained:

Vit. A, 3350000 IU; Vit. D3, 760000 IU; Vit. E, 6700 IU; Vit. K3, 335 mg; Vit. B1, 334 mg; Vit. B2, $1670 \mathrm{mg}$; Vit. B6, 500 mg; Vit. B12, 3.4 mg; Niacin, 10000 mg; Ca. D. Pantothenate, 3334 mg; Biotin, $16.7 \mathrm{mg}$; Folic acid, $334 \mathrm{mg}$;

Trace minerals: Iron, 13350 mg; Copper, 3335 mg; Zinc, 16700 mg; Manganese, 25000 mg; Iodine, $500 \mathrm{mg}$; Cobalt, $84 \mathrm{mg}$; Selenium, $100 \mathrm{mg}$.

Additives: Ethoxyquine $600 \mathrm{mg}$

Carrier (ca co3) up to $1 \mathrm{~kg}$ 
Kawsar A. Ghaly et. al.

Table (2): Averages of some blood serum constituent calcium and values \pm SE as affected by enzymes supplementation into different sorghum-soybean meal based diets

\begin{tabular}{|c|c|c|c|c|c|c|}
\hline Treat. & $\begin{array}{l}\text { Glucose } \\
\text { mg/dl }\end{array}$ & $\begin{array}{l}\text { T. } \\
\text { protein } \\
\text { g/dl }\end{array}$ & $\begin{array}{l}\text { Albumin. } \\
\text { g/dl }\end{array}$ & $\begin{array}{c}\text { Globulin } \\
\text { g/dl }\end{array}$ & $\begin{array}{l}\text { Cal. } \\
\text { mg/dl }\end{array}$ & $\begin{array}{l}\text { Phos. } \\
\text { mg/dl }\end{array}$ \\
\hline $\begin{array}{l}\text { Effect of enzymes: } \\
\text { Without } \\
\text { With } \\
\text { SE } \pm\end{array}$ & $\begin{array}{l}324.83^{\mathrm{b}} \\
416.34^{\mathrm{a}} \\
\pm 9.28\end{array}$ & $\begin{array}{r}3.11^{\mathrm{b}} \\
5.01^{\mathrm{a}} \\
\pm 0.27\end{array}$ & $\begin{array}{l}1.34^{\mathrm{b}} \\
2.02^{\mathrm{a}} \\
\pm 0.22\end{array}$ & $\begin{array}{r}1.74^{\mathrm{b}} \\
2.79^{\mathrm{a}} \\
\pm 0.289\end{array}$ & $\begin{array}{r}6.58^{\mathrm{b}} \\
8.60^{\mathrm{a}} \\
\pm 0.264\end{array}$ & $\begin{array}{r}6.49^{\mathrm{b}} \\
8.68^{\mathrm{a}} \\
\pm 0.237\end{array}$ \\
\hline Significant & $* *$ & $* *$ & $*$ & $*$ & $* *$ & $* *$ \\
\hline $\begin{array}{l}\text { Effect of diet: } \\
\text { Diet } 1 \\
\text { Diet } 2 \\
\text { Diet } 3 \\
\text { SE } \pm\end{array}$ & $\begin{array}{c}246.17^{\mathrm{c}} \\
471.00^{\mathrm{a}} \\
394.58^{\mathrm{b}} \\
\pm 11.29\end{array}$ & $\begin{array}{c}4.08 \\
4.40 \\
3.68 \\
\pm 0.33\end{array}$ & $\begin{array}{c}2.02 \\
1.50 \\
1.53 \\
\pm 0.27\end{array}$ & $\begin{array}{r}2.08 \\
2.57 \\
2.15 \\
\pm 0.35\end{array}$ & $\begin{array}{r}7.80^{\mathrm{a}} \\
8.28^{\mathrm{a}} \\
6.68^{\mathrm{b}} \\
\pm 0.32\end{array}$ & $\begin{array}{r}7.98^{\mathrm{a}} \\
8.25^{\mathrm{a}} \\
6.52^{\mathrm{b}} \\
\pm 0.29\end{array}$ \\
\hline Significant & $* *$ & $\mathrm{NS}$ & NS & $\mathrm{NS}$ & $*$ & $* *$ \\
\hline $\begin{array}{l}\text { Effect of interaction } \\
\text { (diets } \times \text { enzymes): } \\
\text { Diet } 1 \text { without E. } \\
\text { Diet } 1 \text { with E. } \\
\text { Diet } 2 \text { without E } \\
\text { Diet } 2 \text { with E. } \\
\text { Diet } 3 \text { without E. } \\
\text { Diet } 3 \text { with E. } \\
\text { SE } \pm\end{array}$ & $\begin{array}{c}212.00^{\mathrm{d}} \\
280.33^{\mathrm{c}} \\
422.0^{\mathrm{ab}} \\
520.00^{\mathrm{a}} \\
340.50^{\mathrm{b}} \\
448.67^{\mathrm{a}} \\
\pm 16.83\end{array}$ & $\begin{array}{r}3.20 \\
4.97 \\
3.13 \\
5.70 \\
3.00 \\
4.36 \\
\pm 0.47\end{array}$ & $\begin{array}{r}1.57 \\
2.47 \\
1.10 \\
1.90 \\
1.37 \\
1.70 \\
\pm 0.38\end{array}$ & $\begin{array}{r}1.63 \\
2.53 \\
1.97 \\
3.17 \\
1.63 \\
2.67 \\
\pm 0.50\end{array}$ & $\begin{array}{r}6.50 \\
9.10 \\
7.60 \\
8.97 \\
5.63 \\
7.73 \\
\pm 0.45\end{array}$ & $\begin{array}{r}6.77 \\
9.20 \\
7.47 \\
9.03 \\
5.23 \\
7.80 \\
\pm 0.41\end{array}$ \\
\hline Significant & $*$ & NS & NS & NS & NS & NS \\
\hline
\end{tabular}

Means in the same columns for each treatment having different letters are significantly different $(\mathrm{p}<0.05)$

$\mathrm{NS}=$ not significant $(\mathrm{p}>0.05)$

$*$ = significant at $(\mathrm{p}<0.05)$ level

$* *=$ significant at $(\mathrm{p}<0.01)$ level 
Broiler chicks - Phytase - Enzymes - Physiological responses.

Table (3): Averages of total lipids, liver enzymes and thyroid hormones values as affected by enzymes supplementation into different sorghum-soybean meal based diets

\begin{tabular}{|c|c|c|c|c|c|c|}
\hline \multirow[t]{2}{*}{ Iter } & \multicolumn{6}{|c|}{ Some blood constituents } \\
\hline & $\begin{array}{l}\text { T. lipids } \\
\text { mg/dl }\end{array}$ & $\begin{array}{l}\text { ALT } \\
\text { IU/L }\end{array}$ & $\begin{array}{l}\text { AST } \\
\text { IU/L }\end{array}$ & $\begin{array}{c}\text { T3 } \\
\text { nmol } \\
/ /\end{array}$ & $\begin{array}{c}\mathrm{T4} \\
\mathrm{nmol} / \mathrm{l}\end{array}$ & $\begin{array}{c}\mathrm{T} 3 / \mathrm{T} 4 \\
\text { ratio }\end{array}$ \\
\hline $\begin{array}{l}\text { Effect of } \\
\text { enzymes: }\end{array}$ & $524.1 b$ & 18.94 & 171.11 & 5.66 & 2.94 & 2.173 \\
\hline Without & $614.62 \mathrm{a}$ & 20.22 & 180.78 & 5.40 & 2.23 & 2.694 \\
\hline $\mathrm{SE} \pm$ & \pm 9.00 & \pm 1.18 & \pm 3.55 & \pm 0.42 & \pm 0.416 & 0.414 \\
\hline Significant & $* *$ & NS & NS & NS & NS & NS \\
\hline $\begin{array}{l}\text { Effect of diet: } \\
\text { Diet } 1\end{array}$ & $583.0^{\mathrm{b}}$ & $19.58 \mathrm{a}^{\mathrm{b}}$ & $188.50^{\mathrm{a}}$ & $4.55^{\mathrm{b}}$ & 2.35 & 2.018 \\
\hline Diet 2 & $503.87^{c}$ & $23.0^{\mathrm{a}}$ & $170.50^{\mathrm{b}}$ & $6.63^{\mathrm{a}}$ & 2.67 & 2.868 \\
\hline Diet 3 & $621.17^{\mathrm{a}}$ & $16.17^{\mathrm{b}}$ & $168.83^{\mathrm{b}}$ & $5.44 \mathrm{a}^{\mathrm{b}}$ & 2.66 & 2.425 \\
\hline $\mathrm{SE} \pm$ & \pm 11.03 & \pm 1.44 & \pm 4.35 & \pm 0.52 & \pm 0.50 & 0.508 \\
\hline Significant & $* *$ & $*$ & $*$ & $*$ & NS & NS \\
\hline $\begin{array}{l}\text { Effect of interact. } \\
\text { (diets } \times \text { enzymes): }\end{array}$ & 5513 & 182 & $16733^{b}$ & 400 & 254 & 1373 \\
\hline Diet 1 with E. & 614.70 & 21.0 & $209.7^{\mathrm{a}}$ & 5.09 & 2.17 & 2.663 \\
\hline Diet 2 without $E$ & 460.87 & 23.0 & $172.7^{\mathrm{b}}$ & 7.22 & 2.80 & 3.137 \\
\hline Diet 2 with E. & 546.90 & 23.0 & $168.3^{b}$ & 6.04 & 2.72 & 2.60 \\
\hline Diet 3 without E. & 560.00 & 15.7 & $173.3^{b}$ & 5.77 & 3.49 & 2.010 \\
\hline Diet 3 with E. & 682.30 & 16.7 & $164.3^{\mathrm{b}}$ & 5.09 & 1.82 & 2.820 \\
\hline $\mathrm{SE} \pm$ & \pm 15.60 & \pm 2.04 & \pm 6.15 & \pm 0.73 & \pm 0.72 & 0.718 \\
\hline Significant & NS & NS & $* *$ & NS & NS & NS \\
\hline
\end{tabular}

Means in the same columns for each treatment having different letters are significantly different $(\mathrm{p}<0.05) \quad \mathrm{NS}=$ not significant $(\mathrm{p}>0.05) \quad *=$ significant at $(\mathrm{p}<0.05)$ level

$* *=$ significant at $(\mathrm{p}<0.01)$ level

\section{REFERENCES}

Abdel-Azeem, A., 2011. Influence of qualitative restriction on productive performance of Japanese quails hens. Egypt. Poult. Sci., 31(4): 883-897.

Abou-El-Wafa, S.; El-Husseiny, O. M.; and Shaban, M., 2005. Influence of microbial phytase and energy levels on broiler performance fed low phosphorus diets. $3^{\text {rd }}$ International poultry Conference 4-7 April, 2005 Hurdagha, Egypt.

Acamovic, T., 2001. Commercial application of enzyme technology for poultry production. World Poult. Sci. J., 57: 225-242.

Bedford, M. R., 2000. Exogenous enzymes in monogastric nutrition-their current value and future benefits. Anim. Feed Sci. Tech., 86(1): 1-13.

Buyse, J.; Jassens, K.; Van der Geyten, S.; Van As, P.; Decuypere, E.; and Darras, V. M., 2002. Pre-and postprandial changes in plasma hormone and metabolite levels and hepatic deiodinase activities in meal-fed broiler 
Kawsar A. Ghaly et. al.

chickens. Brit. J. Nutr., 88: 641-653.

Cadogan, J. W.; Sundqvist, S.; Salminen, R. T.; and Puumalainen, K., 2005. Export marketing, interfunctional interactions, and performance consequences. J. Academy marketing Sci., 33(4): 520-535.

Dominguez, A. D.; Cuevas, A. C.; Martinez, B. F.; Coello, C. L.; Gonzalez, A. E., 2009. Effect of supplementing an enzyme mixture in sorghum+soybean meal diets on apparent ileal amino acid and protein digestibility, metabolizable energy, and produdctivity in broilers. Tecnica Pecuaria en Mexico, 47: $15-20$.

Duncan, D. B., 1955. Multiple ranges and multiple F tests. Biometric, 11: 1-42.

El-Merzabani, M. M.; El- Aaser, A. A.; and Zakhary, N. I., 1977. J. Clin. Biochem. 15: 715-718.

Gindler, E. M.; and King, J. D., 1972. Rapid colorimetric determination of calcium in biologic fluids with methylthymol blue. Am. J. Clin. Pathol. 4: 376-382.

Gornall, A. G.; Baradawill, C. J.; and David, M. M., 1949. Determination of serum proteins by means of the biuret reaction. J. Biol. Chem., 2: 751-766.

Hajati, H.; Rezaei, M.; and Sayyahzadeh, H., 2009. The Effects of enzyme supplementation on performance, carcass characteristics and some blood parameters of broilers fed on cornsoybean meal-wheat diets. Int. J. Poult. Sci., 8(12): 1199-1205.

Huang, K. H.; Li, X.; Ravindran, V.; and Bryden, W. L., 2006. Comparison of apparent ileal amino acid digestibility of feed ingredients measured with broilers, layers, and roosters. Poult. Sci., 85: 625634.

Jalali, S.; and Babaei, M., 2012. Effects of supplemental dietary phytase on performance and blood biochemical parameter of broiler chick. Int. J. Biosci., 2: 123-129.
Kies, A. K.; Van hemert, K. A. F.; and Sauer, W. C., 2001. Effect of phytase on protein and amino acid digestibility and energy utilization. World's Poult. Sci., 57: 109-124.

Kout El-Kloub, M. El. Mustafa; Awad, A. L.; and Ghonim, A. I. A., 2010. Response of Domyati ducklings to diets containing different levels of metabolizable energy and crude protein: 1-During growth period. Egypt. Poult. Sci., 30: 535 -564.

Kriegshauser, T. D.; Tuinstra, M. R.; and Hancock, J. D., 2006. Variation in nutritional value of sorghum hybrids with contrasting seed weight characteristics and comparisons with maize in broiler chicks. Crop Sci., 46: 695-699.

Lemme, A.; Ravindran, V.; and Bryden, W. L., 2004. Ileal digestibility of amino acids in feed ingredients for broilers. World Poult. Sci. J., 60(4): 423-437.

Mossad, G. M. M.; and Iben, C., 2009. Effect of dietary energy and protein levels on growth performance, carcass yield and some blood constituents of Japanese quails. (Coturnix coturnix Japonica). Die Bodenkultur, 4: 39-46.

NRC, National Research Council, 1994. Requirements of poultry $9^{\text {th }}$ Edition, National Academy press, Washington, D.CUSA.

Nyannor, E. K. D.; Adedokun, S. A.; Hamaker, B. R.; Ejecta, G.; and Adeola, O., 2007. Nutritional evaluation of high- digestible sorghum for pigs and broiler chicks. J. Anim. Sci., 85: 196-203.

Olukosi, O. A.; Cowieson, A. J.; and Adeola, O., 2007. Age-Related Influence of a Cocktail of Xylanase, Amylase, and Protease or Phytase Individually or in Combination in broilers. Poult. Sci. Association, 86: 776- 86.

Rabie, M. H.; Ismail, F. S. A.; and Sherif, Sara, Kh., 2010. Effect of dietary energy level with probiotic and enzyme addition on performance, nutrient digestibility and carcass traits of broilers. Egypt. Poult. Sci., 30(1): 179-201. 
Ravindran, V.; Cabahug, S.; Ravindran, G.; and Bryden, W. L., 1999. Influence of microbial phytase on apparent ileal amino acid digestibility of feedstuffs for broilers. Poult. Sci., 78: 699-706.

Reitman S.; Frankel S., 1957. A colorimetric method for determination of serum glutamate oxaloacetate and glutamic pyruvate transaminase. Am. J. Clin. Pathol. 28: 56-58.

Sadaka, T. A. A., 2006. Effect of methionine level and enzyme additions on production performance, carcass characteristics, and plasma constituents of El-Salam strain. M. Sc. Thesis, Faculty of Agriculture. Damanhur, Alexandria University.

Safaa, H. M., 2013. Influence of Dietary Enzymes Prepared at Ensiling (ZADO®) from Hatch to 42 Days of Age on Productivity, Slaughter Traits and Blood Constituents in Broiler Chickens. Int. J. Poult. Sci., 12(9): 529-537,

SAS, 2004. Guide for personal computer, SAS institute, Inc., Cary, N. C.

Scanes, C. G.; and Griminger, P., 1990. Endocrine nutrition interactions in birds. J. Exp. Zool., 4: 98-105.

Sebastian, S.; Touchburn, S. P.; Chavez, E. R.; and Lague, P. C., 1997. Apparent digestibility of protein and amino acids in broiler chickens fed a corn-soybean diet supplemented with microbial phytase. Poult. Sci., 76: 1760-1769.

Shanti, H.; Jamal, A.; Kamal, A.; and Adel, A., 2012. Performance and some blood constituents of broilers fed sesame meal supplemented with microbial phytase. Asian Pacific J. Trop. Biomed., 1: $1-8$.

Shehab, A. E.; Kamelia, M. Z.; Khedr, N. E.; Tahia, E. A.; and Esmaeil, F. A., 2012. Effect of Dietary Enzyme Supplementation on Some Biochemical and Hematological Parameters of
Japanese quails. J. Anim. Sci., 2(9): 734739.

Smith, E. R.; Pesti, G. M.; Bakalli, R. I.; Ware, G. O.; and Menten, J. F. M., 1998. Further studies on the influence of genotype and dietary protein on the performance of broilers. Poult. Sci., 77: 1678- 1687.

Subramanian, V.; and Metta, V. C., 2000. Sorghum grain for poultry feed: in Technical and institutional options for sorghum grain mold management: proceedings of an international. pp: 242247

Swennen, Q.; Janssens, G. P. J.; Collin, A.; Bihan-Duval, E. L.; Verbeke, K.; Decuypere, E.; and Buyse, J., 2006. Diet-induced thermogenesis and glucose oxidation in broiler chickens: Influence of genotype and diet composition. Poult. Sci., 85: 731-742.

Swennen, Q.; Janssens, G. P. J.; Millet, S.; Vansant, G.; Decuypere, E.; and Buyse, J., 2005. Effects of substitution between fat and protein on feed intake and its regulatory mechanisms in broiler chickens: Endocrine functioning and intermediary metabolism. Poult. Sci., 84: 1051-1057.

Tietz, N.; and Saunders, W., 1995. Clinical Guide to Laboratory Tests, $3^{\text {rd }}$ ed AACC

Trinder P., 1969. Determination of glucose in blood using glucose oxidase with an alternative oxygen receptor. Ann. Clin. Biochem., 6: 24-27.

Viveros, A.; Brenes, A.; Arija, I.; and Centano, C., 2002. Effects of microbial phytase supplementation on mineral utilization and serum enzymes activities in broiler chicks fed different levels of phosphorus. Poult. Sci., 81:1172-1183.

Zollner, N.; and Kirsch, K., 1962. Test combination of the total lipids. ZagesExp. Med., 135: 545-561. 


\section{الملخص العربي}

\section{تأثير إضافة الفايتيز و مخلوط الإنزيمات على بعض المقاييس الفسيولوجية لكتاكيت التسمين}

كوثر عبدالرحمن غالي؛ شاكر عبدالتواب عبداللطيف؛ أحمد محمد أحمد عثمان؛ خيري عبدالحميد محمد؛ مها أحمد

\section{عبداللطيف}

قسم الإنتاج الحيو انى، كلية الزراعة ، جامعة المنيا، مصر

أجريت هذه التجربة لدر اسة تأثثير إضافة خليط من الإنزيمات إلي علائق الذرة الرفيعة وكسب فول الصويا الإبات المحتوية علي

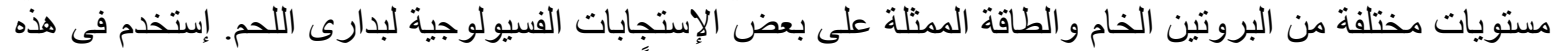

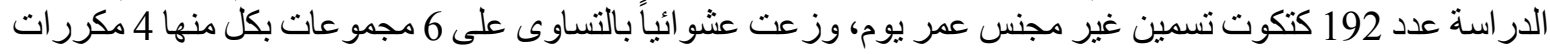

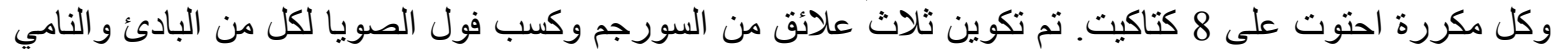

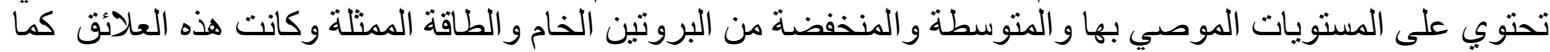

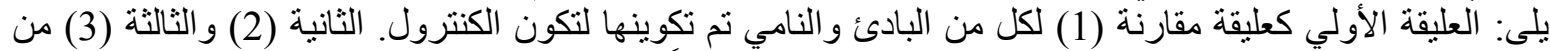

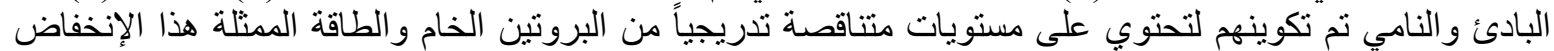

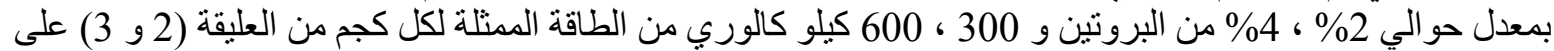

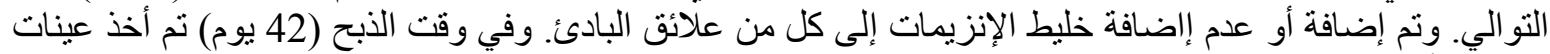

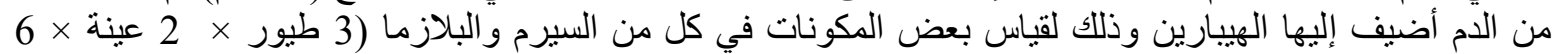

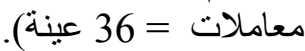
وأوضحت النتائج ما يلى على

إزدادت قيم كلاً من الجلوكوز (ملجم / 100 مل)، البروتين الكلى (جم/100 ملإئ) وكل من الألبيومين و الجلوبيولين،

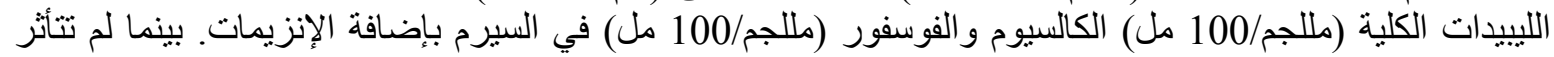

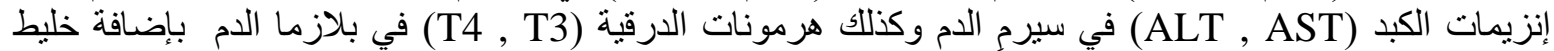

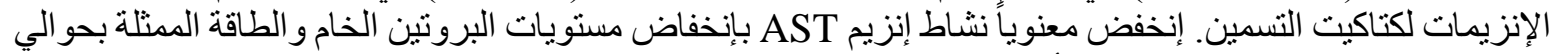

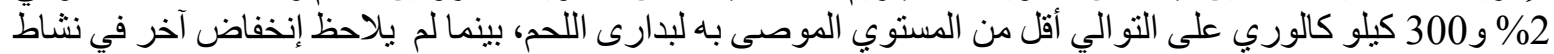

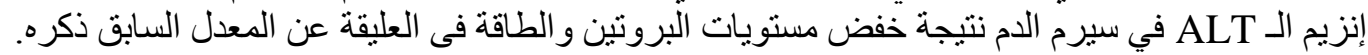

الإستنتاج:

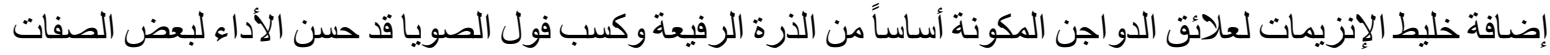

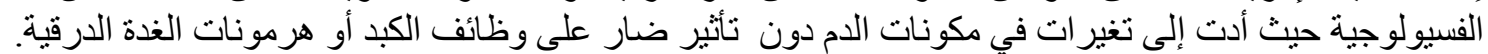

